\title{
In vitro anthelmintic efficacy of Citrullus colocynthis (L.) Schrad on Haemonchus contortus
}

\author{
Tauseef Rehman ${ }^{1}$, Khalid J. Iqbal' ${ }^{2}$ Azra Anwer' ${ }^{2}$,ao Z. Abbas ${ }^{3 *}$, Wasim Babar ${ }^{4}$, \\ Ahmad Ali' ${ }^{2}$ Muhammad K. Khan ${ }^{3}$, Arshad Javid ${ }^{5}$, Noor Khan ${ }^{5}$, Hafiz M. Ali', \\ Faisal Shahzad ${ }^{1}$, Muhammad A. Zaman ${ }^{6}$, and Arbab Sikandar ${ }^{7}$ \\ ${ }^{1}$ University College of Veterinary and Animal Sciences, The Islamia University of Bahawalpur, Pakistan \\ ${ }^{2}$ Department of Zoology, The Islamia University of Bahawalpur, Pakistan \\ ${ }^{3}$ Department of Parasitology, University of Agriculture, Faisalabad, Pakistan \\ ${ }^{4}$ Cholistan University of Veterinary and Animal Sciences, Bahawalpur, Pakistan \\ ${ }^{5}$ University of Veterinary and Animal Sciences, Lahore, Pakistan \\ ${ }^{6}$ Department of Pathobiology, College of Veterinary and Animal Sciences, Jhang, Pakistan \\ ${ }^{7}$ Department of Anatomy, College of Veterinary and Animal Sciences, Jhang, Pakistan
}

REHMAN, T., K. J. IQBAL, A. ANWER, R. Z. ABBAS, W. BABAR, A. ALI, M. K. KHAN, A. JAVID, N. KHAN, H. M. ALI, F.SHAHZAD, M. A. ZAMAN, A. SIKANDAR: In vitro anthelmintic efficacy of Citrullus colocynthis (L.) Schrad on Haemonchus contortus. Vet. arhiv 91, 309-318, 2021.

\section{ABSTRACT}

Ethno-veterinary medicinal studies associated with traditional uses of the flora of the Cholistan desert have shown that fruits of Citrullus colocynthis are used for the treatment of helminth infections. The present research was designed to evaluate the anthelmintic efficacy of $C$. colocynthis against $H$. contortus. The in vitro anthelmintic effects of aqueous-methanol and ethyl acetate fruit extracts of $C$. colocynthis against $H$. contortus were determined through egg hatch and adult motility assays. The effect of four serial dilutions of $25 \mathrm{mg} / \mathrm{mL}$ of each extract compared to levamisol $(0.55 \mathrm{mg} / \mathrm{mL})$ and oxfendazole (three serial dilutions of $25 \mu \mathrm{g} / \mathrm{mL}$ ) were studied. Both ethyl acetate and aqueous-methanol extracts paralyzed all adult worms $4 \mathrm{~h}$ and $8 \mathrm{~h}$ post-exposure at a dose of $25 \mathrm{mg} / \mathrm{mL}$ each. In the egg hatch assay, about $83.67 \%$ and $80.67 \%$ of $H$. contortus eggs failed to hatch with the same dose (i.e. $25 \mathrm{mg} / \mathrm{mL})$ of ethyl acetate and CAME extracts, respectively. The results of the present study strongly support fruit extracts of C. colocynthis as a promising alternative to synthetic drugs against $H$. contortus. These findings will lead to further in vivo studies to investigate the bio-availability of the active ingredients of the plant and the minimum non-lethal concentration required for treatment of haemonchosis in livestock. The anthelmintic effects of C. colocynthis might be attributed to the presence of phenolic acids.

Key words: anthelmintic efficacy; C. colocynthis; H. contortus; egg hatch assay; adult motility assay

\footnotetext{
*Corresponding author:

Rao Z. Abbas, Department of Parasitology, University of Agriculture, Faisalabad, Pakistan, E-mail: raouaf@hotmail.com
} 


\section{Introduction}

Livestock production is a foremost earning source for the agricultural sustainability of poor farmers in rural areas, especially when crop production is not a profitable source of income (KHAJURIA et al., 2013; AHMED et al., 2020). However, parasitism has always caused major problems in achieving maximum output from livestock production systems (MEHMOOD et al., 2017; IJAZ et al., 2018; NASIR et al., 2018; ZAFAR et al., 2019; AHMAD et al., 2019; BATOOL et al., 2019; LI et al., 2019a, 2019b; KHATER et al., 2020; LI et al., 2020). Haemonchus (H.) contortus, the causative agent of haemonchosis, is one of the major hindrances to small ruminant production (BIBI et al., 2017), and causes an estimated loss of about ten billion dollars annually to the veterinary market (ROEBER et al., 2013). A single parasite sucks approximately $0.05 \mathrm{mLblood}$ daily (ALIM et al., 2016) and consequently severely damages the gastrointestinal mucosa (SINGH et al., 2015). Continuous blood loss due to $H$. contortus causes anemia, anorexia, edema, diarrhea, hypoproteinemia, and emaciation, that ultimately lead to the death of the animal (GITHIGIA et al., 2001). Severe infection inflicts a substantial impact on milk, meat and wool production, reduces weight gain by $23-63 \%$, and in $25 \%$ cases death occurs before weaning (SINGH et al., 2015).

Anthelmintic treatment is a leading prophylactic application used against parasitic infection (CARVALHO et al., 2012). However, frequent and prolonged use with undiscriminating administration and improper formulations of synthetic drugs has regrettably led to an upsurge in resistance in the parasites against these salts (DEVI et al., 2014). As a result, $H$. contortus is resistant to all broad range anthelmintic families such as benzimidazole, ivermectin and imidazothiazole and is hence becoming an irrefutable problem (DEVI et al., 2014). Resistant parasites become more pathogenic, prolific and acquire increased adaptability and survivability in all their free-living phases in the host (SANYAL et al., 2003). Apart from resistance against anthelmintics, toxic residues, the high cost of production and the unavailability and inaccessibility of these synthetic drugs, especially in remote rural areas, have spurred investigations to explore alternative methods (QADIR et al., 2010). Among the alternatives, botanicals have been very effective against a wide range of parasites (ABBAS et al., 2017a, 2017b, 2018, 2019; HUSSAIN et al., 2017; IDRIS et al., 2017; ZAMAN et al., 2017; KHATER et al., 2018; FAYAZ et al., 2019). Plants have many bioactive compounds that can easily kill parasites through multiple mechanisms, and ultimately reduce the chances of the development of anthelmintic resistance. Plants are not only ecofriendly and easily biodegradable, but also their bioactive compounds have less chance of bioaccumulation in animal tissues and the surrounding environment (DELFIN et al., 2017).

More reliable and inexpensive herbal medicines are being developed for rapid detection of their active ingredients against the different phases of $H$. contortus. Amongst these, Citrullus (C.) colocynthis, from the Cucurbitaceae family, is highly xerophytic with large perennial roots, triangular leaves, ovoid brown seeds, and globular green fruit containing white pulp and monoecious flowers (PRESTON et al., 2015). The anthelmintic activity of the fruit of C. colocynthis (Voucher \# Ch-03) has been previously documented by conducting a survey (July 2010-January 2011) among local respondents in the Cholistan desert, using closed and open ended questionnaires. About 86 plant-based remedies were recorded, of which the helminthiasis treatment was found to be most frequent. Local shepherds use dry fruit powder from $C$. colocynthis to treat helminthiasis (RAZA et al., 2014). In the current study, the anthelmintic efficacy of fruit extracts of C. colocynthis was investigated against the most pathogenic and prevalent $H$. contortus.

\section{Materials and methods}

Collection of plant fruit. Fruit from C. colocynthis was collected during the month of February, 2017. The plants were identified by a botanist from the Cholistan Institute of Desert Studies, and voucher specimen was deposited in the herbarium of the Cholistan Institute of Desert Studies (CIDSHB54). The collected fruit was washed, dried in shade, pulverized into a coarse powder using a mechanical grinder, and later stored at $4{ }^{\circ} \mathrm{C}$ in air-tight bottles.

Reagents. All analytical grade chemicals were purchased from Sigma (Sigma-Aldrich, St-Quentin Fallavier, France). 
Preparation of extracts in aqueous-methanol and ethyl-acetate. The preparation of fruit extracts were performed according to the methods previously adopted by IQBAL et al. (2012). For extract preparation in aqueous-methanol solution, fruit powder $(50 \mathrm{~g})$ was mixed into sufficient amount of $70 \%$ aqueous-methanol solution for three days, with stirring three times per day for five minutes, and later filtered using porous cloth. The residual plant material was mixed again in aqueous-methanol, and the whole procedure was repeated twice. The three filtrates were then combined and the solvent was evaporated using a rotary evaporator at $40{ }^{\circ} \mathrm{C}$ under reduced pressure. Later evaporation of solvent was completed in a water bath at $65^{\circ} \mathrm{C}$. Finally, crude aqueous methanolic extract (CAME) was stored at $4{ }^{\circ} \mathrm{C}$ in the form of a paste.

The procedure was repeated similarly to prepare the extract in ethyl acetate. Thus, fruit powder $(50 \mathrm{~g})$ was soaked in a sufficient amount of ethyl acetate and the further procedure was repeated three times as described above and finally, the paste was stored at $4{ }^{\circ} \mathrm{C}$

High performance liquid chromatography (HPLC) analysis for flavonoids and phenolic compounds. The hydrolysis of CAME was performed as described previously by DEK et al. (2011). Briefly, CAME (50 mg) was weighed and dissolved in $24 \mathrm{~mL}$ of methanol. After homogenization, $16 \mathrm{~mL}$ of distilled water and 10 $\mathrm{mL}$ of $6 \mathrm{M} \mathrm{HCl}$ were added to the mixture in order. Then mixture was incubated for $2 \mathrm{~h}$ at $95{ }^{\circ} \mathrm{C}$. It was filtered through a $0.45 \mu \mathrm{m}$ nylon membrane filter (Biotech, Germany) prior to HPLC analysis.

The separation of CAME by gradient HPLC (LC-10A, SHIMADZU, JAPAN) was performed using a shim-pack CLC-ODS (C118), $25 \mathrm{~cm} \times 4.6$ $\mathrm{mm}, 5 \mu \mathrm{m}$ column. The chromatographic separation was carried out as mobile phase gradient: A (H2O: Acetic acid-94:6, $\mathrm{pH}=2.27$ ), $\mathrm{B}$ (acetonitrile 100\%). The gradient used was $15 \%$ solvent B (0-15 min), $45 \%$ solvent B (15-30 min) and $100 \%$ solvent B (35-45 min) with $1 \mathrm{~mL} / \mathrm{min}$ flow rate. A UV- visible detector $(\lambda \max 280 \mathrm{~nm}$ ) was used for separation of flavonoids and phenolic acids.

Determination of anthelmintic activity

Adult motility assay. Adult motility assay was performed following the methodology of IQBAL et al. (2012) with modifications. About ten mature adult worms of the same size were collected from the abomasum of freshly slaughtered sheep, washed in PBS and transferred to separate petri dishes containing different concentrations of one of the plant extracts. Two-fold serial dilutions of both extracts were prepared from a $25 \mathrm{mg} / \mathrm{mL}$ concentration of stock solutions by mixing in PBS. Three replications of each concentration and of each control group were carried out as follows:

Aqueous-methanol extract: 25, 12.5, 6.25, $3.12 \mathrm{mg} / \mathrm{mL}$ Ethyl acetate extract: $25,12.5,6.25,3.12 \mathrm{mg} / \mathrm{mL}$

Levamisol: $0.55 \mathrm{mg} / \mathrm{mL}$

PBS: $20 \mathrm{~mL} /$ petri plate

Motility was observed under an inverted microscope at intervals of $0,2,4,6,8,10,12$ hours. The worms that did not show any motility in either the head or tail region were picked out and kept in lukewarm PBS for five minutes, and these worms were only counted as alive if their motility revived.

Egg hatch assay. Egg hatch assay was performed following the guidelines of the "World Association for the Advancement of Veterinary Parasitology" with modifications (ALAWA et al., 2003). To release the eggs, female worms were triturated in a mortar containing PBS. The mixture was filtered using a mesh sieve with $80 \mu \mathrm{m}$ pores, and then the sieve was washed with PBS. The collected fluid was diluted to a concentration of $200 \mathrm{eggs} / \mathrm{mL}$. Four doses of each plant extract and three concentrations of oxfendazole were used in triplicates in 24 multiwell plates as follows:

Aqueous-methanol extract: $25,12.5,6.25,3.125 \mathrm{mg} / \mathrm{mL}$ Ethyl acetate extract: $25,12.5,6.25,3.125 \mathrm{mg} / \mathrm{mL}$ Oxfendazole: $25,12.5,6.125 \mu \mathrm{g} / \mathrm{mL}$

PBS: $1 \mathrm{~mL} /$ well

After incubation at $28{ }^{\circ} \mathrm{C} / 48 \mathrm{~h}$ unhatched eggs were counted under an inverted microscope. The percentage ratios of unhatched eggs were calculated by dividing the final number of unhatched eggs by the initial number of unhatched eggs.

Statistical analysis. The collected data on unhatched eggs was subjected to probit analysis, and data on the adult motility assay were analyzed using SPSS. $\mathrm{P}<0.05$ was considered as the statistically significant level. 


\section{Results}

Adulticidal effects. The adulticidal effect of ethyl acetate and aqueous methanol fruit extract of C. colocynthis is presented in Table 1. Ethyl acetate extract of $C$. colocynthis, even at lower concentrations $(6.25 \mathrm{mg} / \mathrm{mL}$ and $3.125 \mathrm{mg} / \mathrm{mL})$, revealed its maximum effect at the end of the time period, i.e. $12 \mathrm{~h}$. The dose of $25 \mathrm{mg} / \mathrm{mL}$ paralyzed all the worms in only $4 \mathrm{~h}$ after the start of the experiment. The highest tested concentration (25 $\mathrm{mg} / \mathrm{mL}$ ) of aqueous-methanolic extract paralyzed all the worms $8 \mathrm{~h}$ post-exposure, while the lower doses showed their extreme activity in about $10 \mathrm{~h}$ after the start of the experiment. Therefore, the inhibitory potential of ethyl acetate extract was found to be greater than the aqueous-methanol extract. However, both extracts demonstrated a dose dependent effectiveness against the motility and mortality of the worms, ratifying their anthelmintic activity. Moreover, ethyl acetate extract exhibited comparable efficiency to Levamisole at higher dose, of $25 \mathrm{mg} / \mathrm{mL}$. No death was recorded up until the end of the experiment (12h) by PBS, that was used as a negative control.
Ovicidal effects. Table 2 shows the ovicidal effect of $C$. colocynthis ethyl acetate and aqueous methanol fruit extract. Ethyl acetate extract of $C$. colocynthis exhibited maximum ovicidal efficacy $(83.67 \%)$ at the highest tested dose of $25 \mathrm{mg} / \mathrm{mL}$ $(\mathrm{P}<0.05)$. Serially diluted concentrations of ethyl acetate extract inhibited egg hatching in a dose dependent manner. The highest dose of aqueous methanolic extract $(25 \mathrm{mg} / \mathrm{mL})$ inhibited the development of $80.67 \%$ eggs into larvae, while lower doses displayed a similar pattern of inhibition of egg hatching to the ethyl acetate extract - in a dose dependent manner. Ethyl acetate extract demonstrated slightly higher effectiveness than the aqueous-methanol extract.

Flavonoids and phenolic compounds. The data from the HPLC analysis of C. Colocynthis aqueous methanolic extract in the current study showed that the amount of phenolic acids ( $m$-coumaric acid, gallic acid, vanillic acid) varied from $2.23 \pm 0.01$ to $10.48 \pm 0.03 \mathrm{ppm}$, while the amount of flavonoids (quercetin) was $2.49 \pm 0.02 \mathrm{ppm}$.

Table 1. In vitro anthelmintic efficacy of various $C$. colocynthis ethyl acetate extract concentrations against H. contortus, in comparison with Levamisol and PBS

\begin{tabular}{|l|c|c|c|c|c|c|c|}
\hline & 0 hour & 2 hour & 4 hour & 6 hour & 8 hour & 10 hour & 12 hour \\
\hline Lev $0.55 \mathrm{mg} / \mathrm{mL}$ & $0.00 \pm 0.00^{\mathrm{i}}$ & $10.00 \pm 0.00^{\mathrm{a}}$ & $10.00 \pm 0.00^{\mathrm{a}}$ & $10.00 \pm 0.00^{\mathrm{a}}$ & $10.00 \pm 0.00^{\mathrm{a}}$ & $10.00 \pm 0.00^{\mathrm{a}}$ & $10.00 \pm 0.00^{\mathrm{a}}$ \\
\hline PBS & $0.00 \pm 0.00^{\mathrm{i}}$ & $0.00 \pm 0.00^{\mathrm{i}}$ & $0.00 \pm 0.00^{\mathrm{i}}$ & $0.00 \pm 0.00^{\mathrm{i}}$ & $0.00 \pm 0.00^{\mathrm{i}}$ & $0.00 \pm 0.00^{\mathrm{i}}$ & $0.00 \pm 0.00^{\mathrm{i}}$ \\
\hline $3.125 \mathrm{mg} / \mathrm{mL}$ & $0.00 \pm 0.00^{\mathrm{i}}$ & $0.00 \pm 0.00^{\mathrm{i}}$ & $1.67 \pm 0.68^{\mathrm{g}}$ & $4.33 \pm 0.33^{\mathrm{e}}$ & $7.00 \pm 0.00^{\mathrm{c}}$ & $9.00 \pm 0.00^{\mathrm{b}}$ & $10.00 \pm 0.00^{\mathrm{a}}$ \\
\hline $6.25 \mathrm{mg} / \mathrm{mL}$ & $0.00 \pm 0.00^{\mathrm{i}}$ & $0.00 \pm 0.00^{\mathrm{i}}$ & $0.67 \pm 0.33^{\mathrm{h}}$ & $3.33 \pm 0.67^{7 \mathrm{f}}$ & $6.00 \pm 1.00^{\text {cd }}$ & $9.00 \pm 0.58^{\mathrm{b}}$ & $10.00 \pm 0.00^{\mathrm{a}}$ \\
\hline $12.5 \mathrm{mg} / \mathrm{mL}$ & $0.00 \pm 0.00^{\mathrm{i}}$ & $1.00 \pm 0.58^{\mathrm{g}}$ & $4.00 \pm 1.53^{\mathrm{e}}$ & $8.00 \pm 1.00^{\text {bc }}$ & $10.00 \pm 0.00^{\mathrm{a}}$ & $10.00 \pm 0.00^{\mathrm{a}}$ & $10.00 \pm 0.00^{\mathrm{a}}$ \\
\hline $25 \mathrm{mg} / \mathrm{mL}$ & $0.00 \pm 0.00^{\mathrm{i}}$ & $9.67 \pm 0.33^{\mathrm{ab}}$ & $10.00 \pm 0.00^{\mathrm{a}}$ & $10.00 \pm 0.00^{\mathrm{a}}$ & $10.00 \pm 0.00^{\mathrm{a}}$ & $10.00 \pm 0.00^{\mathrm{a}}$ & $10.00 \pm 0.00^{\mathrm{a}}$ \\
\hline
\end{tabular}

Table 2. In vitro anthelmintic efficacy of various $C$. colocynthis aqueous-methanol extract concentrations against H. contortus in comparison with Levamisol and PBS

\begin{tabular}{|l|c|c|c|c|c|c|c|}
\hline & 0 hour & 2 hour & 4 hour & 6 hour & 8 hour & 10 hour & 12 hour \\
\hline Lev $0.55 \mathrm{mg} / \mathrm{mL}$ & $0.00 \pm 0.00^{\mathrm{k}}$ & $5.67 \pm 0.33^{\mathrm{f}}$ & $10.00 \pm 0.00^{\mathrm{a}}$ & $10.00 \pm 0.00^{\mathrm{a}}$ & $10.00 \pm 0.00^{\mathrm{a}}$ & $10.00 \pm 0.00^{\mathrm{a}}$ & $10.00 \pm 0.00^{\mathrm{a}}$ \\
\hline PBS & $0.00 \pm 0.00^{\mathrm{k}}$ & $0.00 \pm 0.00^{\mathrm{k}}$ & $0.00 \pm 0.00^{\mathrm{k}}$ & $0.00 \pm 0.00^{\mathrm{k}}$ & $0.00 \pm 0.00^{\mathrm{k}}$ & $0.00 \pm 0.00^{\mathrm{k}}$ & $0.00 \pm 0.00^{\mathrm{k}}$ \\
\hline $3.125 \mathrm{mg} / \mathrm{mL}$ & $0.00 \pm 0.00^{\mathrm{k}}$ & $0.00 \pm 0.00^{\mathrm{k}}$ & $3.00 \pm 0.00^{\mathrm{h}}$ & $5.00 \pm 0.00^{\mathrm{f}}$ & $8.33 \pm 0.67^{\mathrm{bc}}$ & $10.00 \pm 0.00^{\mathrm{a}}$ & $10.00 \pm 0.00^{\mathrm{a}}$ \\
\hline $6.25 \mathrm{mg} / \mathrm{mL}$ & $0.00 \pm 0.00^{\mathrm{k}}$ & $1.67 \pm 0.33^{\mathrm{j}}$ & $3.67 \pm 0.33^{\mathrm{g}}$ & $6.67 \pm 0.33^{\mathrm{e}}$ & $8.33 \pm 0.33^{\mathrm{bc}}$ & $9.67 \pm 0.33^{\mathrm{ab}}$ & $10.00 \pm 0.00^{\mathrm{a}}$ \\
\hline $12.5 \mathrm{mg} / \mathrm{mL}$ & $0.00 \pm 0.00^{\mathrm{k}}$ & $2.00 \pm 0.58^{\mathrm{j}}$ & $4.00 \pm 0.58^{\mathrm{g}}$ & $7.67 \pm 0.33^{\text {cd }}$ & $9.00 \pm 0.00^{\mathrm{b}}$ & $10.00 \pm 0.00^{\mathrm{a}}$ & $10.00 \pm 0.00^{\mathrm{a}}$ \\
\hline $25 \mathrm{mg} / \mathrm{mL}$ & $0.00 \pm 0.00^{\mathrm{k}}$ & $2.67 \pm 0.67^{\mathrm{hi}}$ & $5.67 \pm 0.67^{\text {fe }}$ & $8.33 \pm 0.33^{\mathrm{bc}}$ & $10.00 \pm 0.00^{\mathrm{a}}$ & $10.00 \pm 0.00^{\mathrm{a}}$ & $10.00 \pm 0.00^{\mathrm{a}}$ \\
\hline
\end{tabular}


Table 3. The percentage of egg hatch inhibition by $C$. colocynthis ethyl acetate extract on $H$. contortus eggs

\begin{tabular}{|l|c|c|}
\hline Products & Concentrations & Percentage inhibition of hatching \\
\hline \multirow{3}{*}{ Oxfendazole $(\mu \mathrm{g} / \mathrm{mL})$} & $25 \mu \mathrm{g} / \mathrm{mL}$ & $77.67 \pm 2.96$ \\
\cline { 2 - 3 } & $12.5 \mu \mathrm{g} / \mathrm{mL}$ & $59.33 \pm 6.94$ \\
\cline { 2 - 3 } & $6.25 \mu \mathrm{g} / \mathrm{mL}$ & $46.67 \pm 5.70$ \\
\hline PBS & $1 \mathrm{~mL} / \mathrm{well}$ & $37.00 \pm 2.08$ \\
\hline Ethyl acetate & $25 \mathrm{mg} / \mathrm{mL}$ & $83.67 \pm 1.20$ \\
\hline \multirow{3}{*}{ fruit extract $(\mathrm{mg} / \mathrm{mL})$} & $12.5 \mathrm{mg} / \mathrm{mL}$ & $77.30 \pm 13.1$ \\
& $6.25 \mathrm{mg} / \mathrm{mL}$ & $73.00 \pm 4.51$ \\
\cline { 2 - 3 } & $3.125 \mathrm{mg} / \mathrm{mL}$ & $58.00 \pm 1.00$ \\
\cline { 2 - 3 } & & \\
\hline
\end{tabular}

Table 4. The percentage of egg hatch inhibition by C. colocynthis aqueous-methanol extract on H. contortus eggs

\begin{tabular}{|l|c|c|}
\hline \multirow{3}{*}{ Products } & Concentrations & Percentage inhibition of hatching \\
\hline \multirow{3}{*}{ PBfendazole $(\mu \mathrm{g} / \mathrm{mL})$} & $25 \mu \mathrm{g} / \mathrm{mL}$ & $82.33 \pm 2.73$ \\
\cline { 2 - 3 } & $12.5 \mu \mathrm{g} / \mathrm{mL}$ & $60.67 \pm 3.53$ \\
\cline { 2 - 3 } & $6.25 \mu \mathrm{g} / \mathrm{mL}$ & $61.33 \pm 8.37$ \\
\hline Aqueous-methanol & $1 \mathrm{~mL} / \mathrm{well}$ & $40.00 \pm 2.65$ \\
\hline \multirow{3}{*}{ fruit extract $(\mathrm{mg} / \mathrm{mL})$} & $25 \mathrm{mg} / \mathrm{mL}$ & $80.67 \pm 3.33$ \\
\hline & $12.5 \mathrm{mg} / \mathrm{mL}$ & $75.00 \pm 1.15$ \\
\cline { 2 - 3 } & $6.25 \mathrm{mg} / \mathrm{mL}$ & $69.00 \pm 4.51$ \\
\cline { 2 - 3 } & $3.125 \mathrm{mg} / \mathrm{mL}$ & $57.00 \pm 4.16$ \\
\hline
\end{tabular}

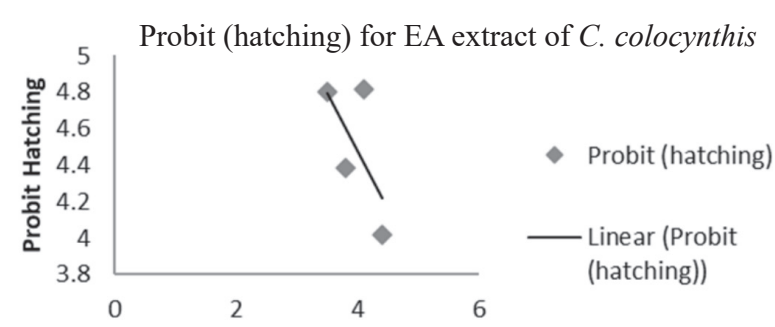

Log concentration of extract

Fig. 1. Linear response of different $C$. colocynthis ethyl acetate extract concentrations on the hatching of H. contortus eggs.
Probit (hatching) for AM extract of C. colocynthis

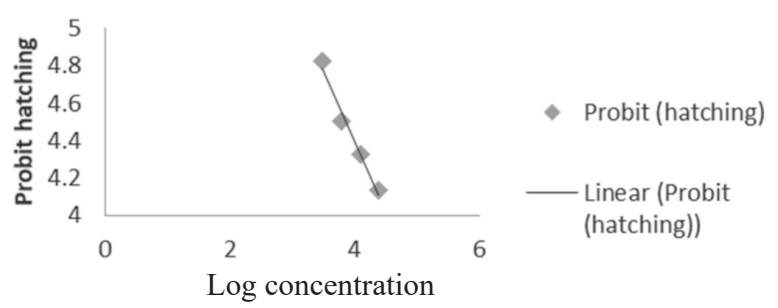

Fig. 2. Linear response of different $C$. colocynthis aqueous methanol extract concentrations on the hatching of $H$. contortus eggs 


\section{Discussion}

Haemonchosis causes an estimated loss to veterinary market of about ten billion dollars annually, and sometimes exceeds the livestock income (ROEBER et al., 2013). Therefore, research and the potential use of novel anthelmintic plant medicines as a substitute for synthetic therapeutics, such as C. colocynthis fruit extracts, offers the possibility of cheaper, ecofriendly and easily accessible phyto-therapeutic products.

In vitro experimentation plays an imperative role in this context as it shows the direct interactive effect of plant materials on different stages of the life of parasites (FERRIERA et al., 2013). Inhibition of egg hatch assay (COLES et al., 1992), and adult (HOUNZANGBE-ADOTE et al., 2005) and larval (KOTZE et al., 2006) motility assays are usually used for testing the anthelmintic activity of natural drugs.

C. colocynthis has been extensively used by farmers as a traditional treatment against helminthiasis in Cholistan (RAZA et al., 2014). Its anthelmintic efficiency has also been previously explored against Pheretima postumaas (TALOLE et al., 2013), H. contortus (ULLAH et al., 2013) and Orthocoelium scoliocoelium (SWARANAKAR and KUMAWAT, 2014). Petroleum ether, ethanol and aqueous extract of C. colocynthis at $40 \mathrm{mg} /$ $\mathrm{mL}$ inhibited the motility of Pheretima posthumaas after an average time of 10.14, 2.36 and $4.33 \mathrm{~min}$ respectively (TALOLE et al., 2013). A combination of aqueous-methanolic extract of $C$. colocynthis (fruit), Curcuma longa (rhizome) and Peganum harmala (seeds) at $100 \mathrm{mg} / \mathrm{mL}$ leads to the death of all $H$. contortus worms $4 \mathrm{~h}$ post exposure (ULLAH et al., 2013). Furthermore, an alcoholic extract of fruit pulp of C. colocynthis at $40 \mathrm{mg} / \mathrm{mL}$ for $5 \mathrm{~h}$ rendered complete inhibition of motility of Orthocoelium scoliocoelium parasites (SWARNAKAR and KUMAWAT, 2014). The combined synergistic action of aqueous-methanolic extract of three plants including $C$. colocynthis previously reported by ULLAH et al. (2013) against $H$. contortus was only against one of its life cycle stages (adult worms) at $100 \mathrm{mg} / \mathrm{mL}$. However, in the current study, aqueous methanolic and ethyl acetate extracts of the plant inhibited worm motility at $25 \mathrm{mg} / \mathrm{mL}$ at $8 \mathrm{~h}$ and
$4 \mathrm{~h}$ post-exposure, respectively. AHMED et al. (2019) investigated the effect of C. colocynthis in vivo against albendazole resistant Haemonchus in lambs. An extract of C. colocynthis at a dose of 200 $\mathrm{mg} / \mathrm{Kg}$ body weight caused a $95.57 \%$ reduction in fecal egg count, while a dose of $50 \mathrm{mg} / \mathrm{Kg}$ caused a $55.07 \%$ reduction in fecal egg count. This difference may be due to the fact that AHMED et al. (2019) performed an in vivo experiment on albendazole resistant worms. AHMED et al. (2019) observed no untoward response to admiinistration of $200 \mathrm{mg} /$ $\mathrm{mL}$ of $C$. colosynthis to lambs. However, they did not perform any proper study involving histological and biochemical tests to reveal any lethal effect at this dose. From these studies, it is conceivable that the ingredient absorption of plant extracts vary between different worms. The difference in anthelmintic activity of plants may be attributed to difference in solubility of solid materials of plants. Solubility is affected by dissimilarities in polarity of plant components and solvent (MALU et al., 2009)

Egg hatch assay was first designed for analysis of benzimidazole resistance in helminthes, and is now used for screening the anthelmintic efficiency of plants (IQBAL et al., 2012). In egg hatch assays, the active compounds of the plant extract pierce the egg shell, paralyze the first stage larvae, and thus inhibit egg hatching (PONE et al., 2011). Various investigations have explored the varying efficacy of different plants against the eggs of $H$. contortus. Aqueous and alcoholic extracts of Foenicum vulgare induced complete inhibition of hatching, while aqueous and alcoholic extracts of Acokanthera schimperi inhibited hatching of $53.6 \%$ and $87 \%$ Haemonchus eggs, respectively (GETACHEW et al., 2012). Similarly, an aqueous extract of Saba senegalensis at $15 \mathrm{mg} / \mathrm{mL}$ (BELEMLILGA et al., 2016), and ethanolic and aqueous extracts of Moringa oleifera at $15.6 \mathrm{mg} / \mathrm{mL}$ (DELFIN et al., 2017) inhibited hatching of $93.63 \%, 95.89 \%$ and $81.72 \%$ eggs of this parasite, respectively. Moreover, hatching of $46.6 \%$ eggs was inhibited with Eucalyptus globulus leaf methanolic extract, $6.4 \%$ with Annona squamosa, 51.2\% with Syzigium cumini, $82.7 \%$ with Catharanthus roseus (KUAMR et al., 2015), 79.6\% with methanolic and acetonic extract of Khaya senegalensis (CHINA et al., 2016) 
and absolute inhibition with aqueous extracts of Capparis spinosa (AKKARI et al., 2016). PONE et al. (2011) described that the active components of plants inhibit egg hatching by paralyzing the first stage larvae inside the egg shell. Despite these numerous studies, the inhibitory effect of C. colocynthis on egg hatching of any helminth has not yet been investigated. Ethyl acetate and aqueous-methanol fruit extracts of $C$. colocynthis in the current study caused inhibition of hatching of more than $80 \%$ eggs and showed their effectiveness against the parasite. It is remarkable to note that most plant extracts showed a statistically significant anthelmintic effect against the different life-cycle stages of parasites and lower the chances of the development of parasitic resistance (HOUNZANGBE-ADOTE et al., 2005).

Besides their role in inhibition of egg hatching, these plant anthelmintics also affect various worm developmental stages. In this context, an aqueous extract of Saba senegalensis inhibited the motility of $97.77 \% \mathrm{H}$. contortus worms at $15.00 \mathrm{mg} / \mathrm{mL}$ (BELEMLILGA et al., 2016), an acetonic extract of Khaya senegalensis inhibited the motility of $75 \%$ H. contortus worms at $2400 \mu \mathrm{g} / \mathrm{mL}$ (CHINA et al., 2016), a herbal complex prepared from four herbs; Cinnamomum verum, Capsicum annuum, Origanum vulgare and Rosmarinus officinalis caused $100 \% \mathrm{H}$. contortus mortality at $100 \mathrm{mg} / \mathrm{mL}$ (ZAMAN et al., 2020), while a methanolic extract of the same plant caused inhibition of all the $H$. contortus worms even at a half the dose $(1200 \mu \mathrm{g} /$ $\mathrm{mL}$ ) of the acetonic extract (CHINA et al., 2016).

The current study showed that the amount of phenolic acids ( $m$-coumaric acid, gallic acid, vanillic acid) varied from $2.23 \pm 0.01$ to $10.48 \pm 0.03 \mathrm{ppm}$, and the amount of flavonoids (quercetin) was found to be $2.49 \pm 0.02 \mathrm{ppm}$. UMA and SEKAR, (2014) performed phytochemical screening of this plant, and labeled alkaloids and saponins as the active ingredients that might contribute to its anthelmintic activity.

\section{Conclusion}

It is concluded from the current project that bioactive compounds isolated from fruit extracts of $C$. colocynthis could be a strong novel substitute for commercial anthelmintic drugs for the control of this extremely prevalent nematode, $H$. contortus. For this purpose, safety and toxicity studies on $C$. colocynthis should be conducted in vivo to ascertain the minimum non-lethal concentration required for treatment of haemonchosis in livestock.

\section{Statement of novelty}

For the first time, the in vitro anthelmintic activity of aqueousmethanol fruit extracts of $C$. colocynthis against the eggs and adults of $H$. contortus has been studied; the promising alternative to synthetic drugs against this highly prolific parasite is strongly advocated.

\section{References}

ABBAS, A., R. Z. ABBAS, M. K. KHAN, M. A. RAZA, M. S. MAHMOOD, M. K. SALEEMI, T. HUSSAIN, J. A. KHAN, Z. U. D SINDHU (2019): Anticoccidial effects of Trachyspermum ammi (Ajwain) in broiler chickens. Pak. Vet. J. 39, 301-304.

DOI: $10.29261 /$ pakvetj/2019.056

ABBAS, A., R. Z. ABBAS, S. MASOOD, Z. IQBAL, M. K. KHAN, M. K. SALEEMI, M.A. RAZA, M. S. MAHMOOD, J. A. KHAN, Z.D. SINDHU (2018): Acaricidal and insecticidal effects of essential oils against ectoparasites of veterinary importance. Bol. Latinoamerican. Y. Del. Caribe. De. Plant. Med. Y. Aromát. 17, 441-452.

ABBAS, A., Z. IQBAL, R. Z. ABBAS, M. K. KHAN, J. A. KHAN, Z. D. SINDHU, M. S. MAHMOOD, M. K. SALEEMI (2017a): In vivo anticoccidial effects of Beta vulgaris (sugar beet) in broiler chickens. Microb. Path. 111, 139-144.

DOI: 10.1016/j.micpath.2017.07.052

ABBAS, A., Z. IQBAL, R. Z. ABBAS, M. K. KHAN, J. A. KHAN (2017b): Immunomodulatory activity of Pinus radiata extract against coccidiosis in broiler chicken. Pak. Vet. J. 37, 145-149.

AHMAD, N., I. A. KHAN, Z. IQBAL, A. A. NASEEM, A. R. KAYANI, K. AFSHAN, M. QAYYUM (2019): Seroepidemiology of toxoplasmosis in human population with reference to its zoonotic potential in sub-tropical areas of Pakistan. Pak. Vet. J. 39, 211-215.

DOI: $10.29261 /$ pakvetj/2019.017

AHMED, C. N., K. HAMAD, F. A. QADIR (2019): Haemonchus contortus as a model in assessing activity of Citrullus colocynthis fruit extract to control benzimidazoleresistant parasitic nematodes. Zanco. J. Pure. Appl. Sci. 31, 61-70.

DOI: $10.21271 /$ zjpas.31.5.8

AHMED, M. M, M. W. AKRAM, M. H. N. TAHIR, S. B. HUSSAIN, J. ALI, A. A. KEERIO, A. ABBAS (2020): Genetics and association of yield contributing characters 
for achene yield in sunflower (Helianthus annuus L.). Agrobiol. Records. 1, 26-30.

DOI: 10.47278 journal.abr/2020.005

AKKARI, H., F. B. CHIR, S. HAJAJI, M. REKIK, E. SEBAI, H. HAMZA, M. A. DARGHOUTH, M. GHARBI (2016): Potential anthelmintic effect of Capparis spinosa (Capparidaceae) as related to its polyphenolic content and antioxidant activity. Vet. Med. 61, 308-316.

DOI: 10.17221/169/2015-VETMED

ALAWA, C. B. I, A. M. ADAMU, J. O. GEFU, O. J. AJANUSI, P. A. ABDU, N. P. CHIEZEY, J. N. ALAWA, D. D. BOWMAN (2003): In vitro screening of two Nigerian medicinal plants (Vernonia amygdalina and Annona senegalensis) for anthelmintic activity. Vet. Parasitol. 113, 73-81.

DOI: 10.1016/S0304-4017(03)00040-2

ALIM, M. A., Y. FU, Z. WU, S. H. ZHAO, J. CAO (2016): Single nucleotide polymorphisms of Toll-like receptors and association with Haemonchus contortus infection in goats. Pak. Vet. J. 36, 286-291.

BATOOL. M., S. NASIR, A. RAFIQ, I. YOUSAF, M. YOUSAF (2019): Prevalence of tick infestation in farm animals from Punjab, Pakistan. Pak. Vet. J. 39, 406-410.

DOI: $10.29261 /$ pakvetj/2019.089

BELEMLilgA, M. B., A. TRAORE, S. OUEDRAOGO, A. KABORE, H. H. TAMBOURO, I. P. GUISSOU (2016): Anthelmintic activity of Saba senegalensis (A.DC.) Pichon (Apocynaceae) extract against adult worms and eggs of Haemonchus concortus. Asian Pac. J. Trop. Biomed. 6, 945-949.

DOI: $10.1016 /$ j.apjtb.2016.07.015

BIBI, R., K. AFSHAN, I. A. KHAN, Z. IQBAL, A. R. KAYANI, M. MUSHTAQ, M. IRFAN, M. QAYYUM, M. F. HASSAN (2017): Phenotyping and prevalence of Haemonchus contortus (Nematoda: Trichostongylidae) in ruminants from endemic areas of Pakistan: influence of host species and geographical area on phenotypic traits of worms. Pak. Vet. J. 37, 170-174.

CARVAlHO, C. O., A. C. S. CHAGAS, F. COTINGUIBA, M. FURLAN, L. G. BRITO, F. C. M. CHAVES, M. P. STEPHAN, H. R. BIZZO, A. F. AMARANTE (2012): The anthelmintic effect of plant extracts on Haemonchus contortus and Strongyloides venezuelensis. Vet. Parasitol. 183, 260-268.

DOI: 10.1016/j.vetpar.2011.07.051

CHINA, T. F. C., S. ATTINDEHOU, B. A. GBANGBOCHE, S. SALIFOU (2016): In vitro anthelmintic activity of acetonic and methanolic extracts of khaya senegalensis stem bark on Haemonchus contortus. World J. Pharm. Pharma. Sciencesortus. 5, 138-147.

COLES, G. C., C. BAUER, F. H. BORGSTEEDE, S. GEERTS, T. R. KLEI, M. A. TAYLOR, P. J. WALLER (1992): World association for advancement in veterinary parasitology (W.A.A.V.P.) methods for the detection of anthelmintic resistance in nematodes of veterinary importance. Vet. Parasitol. 44, 35-44.

DOI: 10.1016/0304-4017(92)90141-U

DEK, P. M. S., A. OSMAN, N. G. SAHI, N. SAARI, M. MARKOM, A. A. HAMID, F. ANWAR (2011): Effects of extraction techniques on phenolic components and antioxidant activity of Mengkudu (MorindacitrifoliaL.) leaf extracts. J. Med. Plants Res. 5, 5050-5057.

DELFIN, E., J. CABARDO, H. P. PORTUGALIZA (2017): Anthelmintic activity of Moringa oleifera seed aqueous and ethanolic extracts against Haemonchus contortus eggs and third stage larvae. Inter. J. Vet. Sci. Med. 5, 30-34.

DOI: 10.1016/j.ijvsm.2017.02.001

DEVI, K., S. VASANTHA, P. MANOGAR, R. KALPANA (2014): In vitro anthelmintic activity of Actinopteris radiata (sw.) link. Afric. J. Sci. Res. 3, 9-11.

FAYAZ, M. R., R. Z. ABBAS, A. ABBAS, M. K. KHAN, M. A. RAZA, M. ISRAR, J. A. KHAN, M. S. MAHMOOD, M. K. SALEEMI, T. REHMAN, M. A. ZAMAN, Z. D. SINDHU (2019): Potential of botanical driven essential oils against Haemochus contortus in small ruminants. Bol Latinoam. Caribe. Plant. Med. Aromat. 18, 533-543.

DOI: 10.35588/blacpma.19.18.6.36

FERREIRA, P. M. N., A. C. S. CASTROA, S. C. CHAGASB, R. O. FRANCAA, BELEBONIA (2013): In vitro anthelmintic activity of aqueous leaf extracts of Annona muricata L. (Annonaceae) against Haemonchus contortus from sheep L.E. Exp. Parasitol. 134, 327-332.

DOI: 10.1016/j.exppara.2013.03.032

GETACHEW, S., N. IBRAHIM, B. ABEBE, T. EGUALE (2012): In vitro evaluation of anthelmintic activities of crude extracts of selected medicinal plants against Haemonchus Contortus in Ale mgena Wereda Ethiopia. Acta Parasitol. Globalis. 3, 20-27.

DOI: 10.5829/idosi.apg.2012.3.2.64177

GITHIGIA, S. M., S. M. THAMSBORG, W. K. MUNYUA, N. MAINGI (2001): Impact of gastrointestinal helminths on production in goats in Kenya. Small Rumin. Res. 42, 21-29.

DOI: $10.1016 / \mathrm{S} 0921-4488(01) 00240-1$

HOUNZANGBE-ADOTE, M. S., V. PAOLINI, I. FOURASTE, K. MOUTAIROU, H. HOSTE (2005): In vitro effects of four tropical plants on three life-cycle stages of the parasitic nematode Haemonchus contortus. Res. Vet. Sci. 78, 155-160.

DOI: 10.1016/j.rvsc.2004.05.009

HUSSAIN, K., Z. IQBAL, R. Z. ABBAS, M. K. KHAN, M. K. SALEEMI (2017): Immunomodulatory activity of Glycyrrhiza glabra extract against mixed Eimeria infection in chickens. Int. J. Agric. Biol. 19, 928-932.

DOI: 10.17957/IJAB/15.0397

IDRIS, M, R. Z. ABBAS, S. MASOOD, T. REHMAN, U. FAROOQ, W. BABAR, R. HUSSAIN, A. RAZA, U. RIAZ 
(2017): The potential of antioxidant rich essential oils against avian coccidiosis. World. Poult. Sci. J. 73, 89-104. DOI: $10.1017 /$ S0043933916000787

IJAZ, M., M. A. ZAMAN, F. MARIAM, S. H. FAROOQI, A. I. AQIB, S. SALEEM, A. GHAFFAR, A. ALI, R. AKHTAR (2018): Prevalence, hematology and chemotherapy of gastrointestinal helminths in camels. Pak. Vet. J. 38, 81-85. DOI: $10.29261 /$ pakvetj/2018.016

IQBAL, Z., W. BABAR, Z. U. D. SINDHU, R. Z. ABBAS, M. S. SAJID (2012): Evaluation of anthelmintic activity of different fractions of Azadirachta indica A. Juss seed extract. Pak. Vet. J. 32, 579-583

KHAJURIA, J. K., R. KATOCH, A. YADAV, R. GODARA, S. K. GUPTA, A. SINGH (2013): Seasonal prevalence of gastrointestinal helminths in sheep and goats of middle agro-climatic zone of Jammu province. J. Parasit. Dis. 37, 21-25.

DOI: $10.1007 / \mathrm{s} 12639-012-0122-3$

KHATER, H. F., A. M. ALI, G. A. ABOUELELlA, M. A. MARAWAN, M. GOVINDARAJAN, K. MURUGAN, R. Z. ABBAS, N. P. VAZ, G. BENELLI (2018): Toxicity and growth inhibition potential of vetiver, cinnamon, and lavender essential oil and their blends against larvae of the sheep blowfly, Lucillia sericata. Int. J. Dermatol. 57, 449-457.

DOI: $10.1111 /$ ijd. 13828

KHATER, H. F., H. ZIAM, A. ABBAS, R. Z. ABBAS, M. A. RAZA, K. HUSSAIN, E. Z. YOUNIS, I. T. RADWAN, A. SELIM (2020): Avian coccidiosis: Recent advances in alternative control strategies and vaccine development. Agrobiol. Records. 1, 11-25.

DOI: 10.47278 /journal.abr/2020.004

KOTZE, A. C., L. F. LE JAMBRE, J. O'GRADY (2006): A modified larval migration assay for detection of resistance to macrocyclic lactones in Haemonchus contortus, and drug screening with Trichostrongylidae parasites. Vet. Parasitol. 137, 294-305.

DOI: 10.1016/j.vetpar.2006.01.017

KUAMR, S., A. KUMAR, N. KUMAR, N. SHARMA, M. SINGH, D. GOPINATH, V. K. GUPTA (2015): In vitro anthelmintic activity and phytochemical analysis of for tropical plants against Haemonchus contortus. Inter. J. Adv. Res. 3, 541-548.

LI, K., H. LUO, K. MEHMOOD, H. ZHANG, M. SHAHZAD, R.Z. ABBAS (2019a): Sarcosporidiosis: An emerging disease in Yaks (Bos grunniens) on the Qinghai Tibetan Plateau (QTP), China. Acta. Parasitologica. 64, 246-250.

DOI: $10.2478 /$ s11686-019-00032-0

LI, K., L. ZHANG, H. LUO, K. MEHMOOD, M. SHAHZAD, M. U. NASEER (2019b): Besnoitiosis: An emerging parasitic disease in yaks (Bos grunniens) and tibetan sheep (Ovies aries) on the qinghai tibetan plateau, China. Pak. Vet. J. 39, 447-450.

DOI: $10.29261 /$ pakvetj/2019.086
LI, K., H. LUO, K. MEHMOOD, M. SHAHZAD, J. LI (2020): Exploring the potential parasitic pathogens causing diarrheal death to yak calves with bloody excrement through high-throughput sequencing. Agrobiol. Records. $1,1-5$.

DOI: $10.47278 /$ journal.abr/2020.002

MALU, S. P., G. O. OBOCHI, C. A. EDEM, B. E. NYONG (2009): Effect of methods of extraction on phytochemical constituents and antibacterial properties of Tetracarpidium conophorum seeds. Glob. J. Pure Appl. Sci. 15, 373-376.

DOI: $10.4314 /$ gjpas.v15i3-4.48563

MEHMOOD, K., H. ZHANG, A. J. SABIR, R. Z. ABBAS, M. IJAZ, A. Z. DURRANI, M. H. SALEEM, M. U. REHMAN, M. K. IQBAL, Y. WANG, H. I. AHMAD, T. ABBAS, R. HUSSAIN, M. T. GHORI, S. ALI, A. U. KHAN, J. LI (2017): A review on epidemiology, global prevalence and economical losses of fasciolosis in ruminants. Microb. Path. 109, 253-262.

DOI: 10.1016/j.micpath.2017.06.006

NASIR, A., M. A. ZAMAN, A. SHAKOOR, T. U. REHMAN, I. KHAN, S. EHTISHAM-UL-HAQUE, A. SIKANDAR, S. MASOOD, A. AKBAR (2018): Prevalence of Neospora caninum using milk and serum ELISA and its hematological effect in dairy buffaloes. Pak. Vet. J. 38, 281-285.

DOI: $10.29261 /$ pakvetj/2018.039

PONE, J. W., K. T. FLORENCE, M. MBIDA, E. P. TEDONKENG, C. F. B. BILONG (2011): In vitro activities of acetonic extracts from leaves of three forage legumes (Calliandra calotyrsus, Gliricidia sepium and Leucaena diversifolia) on Haemonchus contortus. Asian Pac. J. Trop. Med. 4, 125-128.

DOI: $10.1016 / \mathrm{S} 1995-7645(11) 60051-5$

PRESTON, S. A., C. JABBAR, NOWELL, JOACHIM, B. RUTTKOWSKI, J. BAELL, T. CARDNO, P. K. KORHONEN, D. PIEDRAFITA, B. R. E. ANSELL (2015): Low cost whole-organism screening of compounds for anthelmintic activity. Int. J. Parasitol. 45, 333-443.

DOI: 10.1016/j.ijpara.2015.01.007

QADIR, S., A. K. DIXIT, P. DIXIT (2010): Use of medicinal plants to control Haemonchus contortus infection in small ruminants. Vet. World. 3, 515-518.

DOI: 10.5455/vetworld.2010.515-518.

RAZA, M. A., M. YOUNAS, A. BUERKERT, E. SCHLECHT (2014): Ethno-botanical remedies used by pastoralists for the treatment of livestock diseases in Cholistan desert, Pakistan. J. Ethnopharmacol. 151, 333-342.

DOI: $10.1016 /$ j.jep.2013.10.049

ROEBER, F., A. R. JEX, R. B. GASSER (2013): Nextgeneration molecular-diagnostic tools for gastrointestinal nematodes of livestock, with an emphasis on small ruminants. A turning point? Adv. Parasitol. 83, 267-333. DOI: 10.1016/B978-0-12-407705-8.00004-5 
SANYAL, P. K., C. P. SWANKAR, D. SINGH, F. A. KHAN, P. S. K. BHAGWAN (2003): Sheep and albendazole model for a new approach on judicious use of anthelmintics in small ruminants. J. Vet. Parasitol. 17, 15-19.

SINGH, G., R. SINGH, P. K. VERMA, R. SINGH, A. ANAND (2015): In vitro anthelmintic efficacy of aqueous extract of Scindapsus officinalis (Roxb) schott fruits against Haemonchus contortus of small ruminants. Proc. Natl. Acad. Sci. India. Sect. B. Biol. Sci. 85, 705-709.

DOI: $10.1007 / \mathrm{s} 40011-014-0389-5$

SWARNAKAR, G., A. KUMAWAT (2014): In vitro anthelmintic effect of Citrullus colocynthis on tegument of Amphistome Orthocoelium scoliocoelium (Trematoda: Digenea). Int. J. Curr. Microbial. Appl. Sci. 3, 571-582.

TALOLE, B. B., D. G. BAHETI, P. A. MORE (2013): In vitro helmintholytic activity of leaves of Citrullus colocynthis. Int. J. Res. Pharm. Chem. 3, 240-243.

ULLAH, S., M. S. KHAN, M. S. SAJID, G. MUHAMMUD (2013): Comparative anthelmintic efficacy of Curcuma longa, Citrullus colocynthis and Peganum harmala. Glob. Vet. 1, 560-567.

UMA, C., K. G. SEKAR (2014): Phytochemical analysis of a folklore medicinal plant Citrullus colocynthis L (bitter apple). J. Pharmacogn. Phytochem. 2, 195-202.
ZAFAR, A., M. K. KHAN, Z. U. D SINDHU, R. Z. ABBAS, S. MASOOD, Z. ABBAS, M. S. MAHMOOD, M. K. SALEEMI, J. A.; KHAN, R. HUSSAIN, M. U. NASEER, Z. IQBAL, H. JAVED (2019): Seroprevalence of Fasciola hepatica in small ruminants of District Chakwal, Punjab, Pakistan. Pak. Vet. J. 39, 96-100.

DOI: $10.29261 /$ pakvetj/2018.024

ZAMAN, M. A., Z. IQBAL, Z. U. D. SINDHU, R. Z. ABBAS, M. F. QAMAR (2017): An overview of plants with acaricidal and anthelmintic properties. Int. J. Agric. Biol. 19, 957-968.

DOI: $10.17957 / \mathrm{IJAB} / 15.0289$

ZAMAN, M. I., W. QAMAR, S. YOUSA, U. MEEREEN, Z. SHAHID, M. K. KHAN, M. F. QAMAR, M. KAMRAN (2020): In vitro experiments revealed the anthelmintic potential of herbal complex against Haemonchus contortus. Pak. Vet. J. 40, 271-273.

DOI: $10.29261 /$ pakvetj/2019.128

Received: 2 April 2020

Accepted: 17 November 2020

REHMAN, T., K. J. IQBAL, A. ANWER, R. Z. ABBAS, W. BABAR, A. ALI, M. K. KHAN, A. JAVID, N. KHAN, H. M. ALI, F.SHAHZAD, M. A. ZAMAN, A. SIKANDAR: Procjena in vitro antihelmintičke učinkovitosti Citrullus colocynthis (L.) Schrad u kontroli oblića Haemonchus contortus. Vet. arhiv 91, 309-318, 2021.

\section{SAŽETAK}

Istraživanja etno veterinarske medicine povezana sa tradicionalnom primjenom flore iz pustinje Cholistan pokazala su da u liječenju invazija uzrokovanih helmintima mogu biti uporabljeni plodovi Citrullus colocynthis. Ovo istraživanje je oblikovano s ciljem da se procjeni anthelmintička djelotvornost C. colocynthis u kontroli oblića Haemonchus contortus. Testovi izlijeganja iz jaja i pokretljivosti odraslih jedinki korišteni su za mjerenje antihelmintičkih učinaka vodene otopine metanola i etil acetate ekstrahiranih iz C. colocynthis. Analiziran je učinak četiri serijska razrjeđivanja od $25 \mathrm{mg} / \mathrm{mL}$ svakog ekstrakta u usporedbi s levamisolom $(0,55 \mathrm{mg} / \mathrm{mL})$ i oksfendazolom (tri serijska razrjeđivanja od $25 \mu \mathrm{g} / \mathrm{mL}$ ). Oba ekstrakta, i etil acetata i vodene otopine metanola, paralizirali su sve odrasle crve 4h i $8 \mathrm{~h}$ nakon izlaganja u dozi od $25 \mathrm{mg} / \mathrm{mL}$. U testu izlijeganja jaja, pri istoj dozi $(25 \mathrm{mg} / \mathrm{mL}), 83,67 \%$ jaja $\mathrm{H}$. contortus nije se izleglo nakon uporabe ekstrakta etil acetat, odnosno $80,67 \%$ nakon uporabe otopine metanola. Rezultati ovog istraživanja snažno podupiru ekstrakte ploda $C$. colocynthis kao obećavajuće alternative sintetskim lijekovima protiv oblića $H$. contortus. Za očekivati je daljnja in vivo istraživanja kako bi se utvrdila biodostupnost aktivnih sastojaka biljke i minimalna nesmrtonosna koncentracija potrebna za liječenje invazija stoke sa $H$. contortus. Anthelmintički učinci $C$. colocynthis se mogu pripisati prisutnosti fenolnih kiselina.

Ključne riječi: antihelmintička djelotvornost; $C$. colocynthis; H. contortus; test izlijeganja jaja; test pokretljivosti odraslih parazita 